\title{
2020 年度低侵襲心臓手術（MICS）分野における進歩 Recent Advancement in the Field of MICS
}

\author{
旭川医科大学病院心臓外科白 坂 知 識
}

Tomonori Shirasaka

\section{はじめに}

低侵襲心臟手術 (MICS) は本邦でも年々普及してお り，認知機能や而術能の幅が大きな高齢者に対しては同一 疾患に対してもさまざまな治療選択肢を提案できるように なってきた。

本稿では 2020 年度における本領域の進渉状況を紹介す る.

\section{1. 大動脈弁狭窄症に対する治療選択肢の拡大}

\section{1-1. TAVI}

大動脈弁狭窄症に対する経カテーテル的大動脈弁置換術 (TAVI) が本邦でも普及してきたが，これまでは対象患者 の大多数が開心術への耐術が見込めない 80 歳以上の高齢 者に対するものであったため，低侵襲性が証明されている 一方で TAVI 弁の本邦に打ける長期成績は不明 ${ }^{1)}$ であった。 しかし, 大規模試験の結果 ${ }^{2)}$ 踏まえて 2020 ACC/AHA ガ イドライン ${ }^{3)}$ および $2021 \mathrm{ECC}$ ガイドライン ${ }^{4)}$ では対象年 齢が引き下げられ TAVI 適応が拡大されはじめた. SAPIEN 3 （Edwards Lifescience, Irvine, CA）に関しては，外科 手術の耐術不能例にかぎらず症候性の重症大動脈弁狭窄症 であれば治療対象となるようになっている。またデリバ リーシステムの low profile 化（最小で $23 \mathrm{~mm}$ ）を strong point とする EvolutPRO+ (Medtronic, Minneapolis, Minnesota）は，2020 年 10 月に国内販売が開始され 2021 年 9 月には low riskへの適応が保険収載されることになった。

一方, 実臨床では TAVI 後の遺残大動脈弁逆流 (AR) への追加治療の benefit と弁輪破裂の risk とのバランスを 考えた上，ARがある状態でも治療を終えざるを得ない状 沉を経験する．遺残 AR の程度と術後の心関連事故や死亡

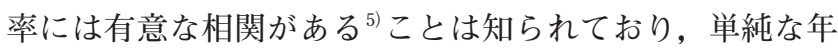
齢だけではなく frailty ${ }^{6)}$ 考慮したうえで認知機能に問題 がなく，全身麻酔・開胸手術への耐術が見込める患者には 年齢のみに拘泥せず解剖学的条件をあくまで優先・重視す べきという意見は，むしろ high volume center から聞こえ てくる意見でもある．現在本邦に打いても心臟外科医が経
大腿動脈アプローチによる TAVI（TF-TAVI）の執刀を経 験している施設は，認定施設全体の $40 \%$ にまで広がって いるのは，心臓外科側も本治療に打ける低侵襲性の魅力を 痛感しているのと同時に，年齢や frailtyによってはっきり と異なるそのアウトカム ${ }^{6}$ を目の当たりにして, 大動脈弁 手術に携わってきた経験を基に年齢・併存疾患・frailty · 手技リスク・耐久性・患者の希望などをすべて加味したう えで，患者ごとのオーダーメイド医療を適切に展開したい という思惑もあるのではないかと思われる.

ところで本領域に打ける新しいトピックの1つに慢性透 析患者への TAVI が 2021 年 1 月より薬事承認されたこと がある. 今のところは厳しい施設基準があり（TAVI 指導 施設もしくは Edwards 社の proctor が在籍している TAVI 専門施設), その初期成績が待たれるが, アクセス不良症 例が多いことが問題の 1 つである. TAVIのアプローチに 関して現在その大半を占めるのはTF-TAVIであるが，今

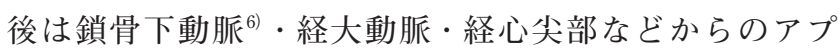
ローチを要する「外科的 TAVI」がかえって増加すること も予想されている.

2013 年から 2017 年にかけてのフランスの大規模レジス トリにおける TF-TAVI（19,995 例）と non TF-TAVI（経総 頸動脈・経鎖骨下動脈（Tsc-TAVI 2,616 例）の成績比較に おいて, non TF-TAVI は術後の死亡率/合併症発生率は TF-TAVI に比し同等の結果, 一方主要血管合併症と予定 外の血管修復においては有意に発生率が低い結果となっ た ${ }^{7)}$.

Tsc-TAVI は TF-TAVI 不適症例における第 2 の peripheral TAVI としての役割を期待されている.すでにアメリ カでは non TF-TAVI 4.7\%のうち, 2.5\%(経大動脈 TAVI=TAo-TAVI 0.5\%, 経心尖 TAVI=TA-TAVI 0.3\%) と 最も頻度が高いアプローチとなっている．2015 年から 2018 年における STS/ACC TVTレジストリ・TAVI 3,628 例の検討（うち， non TF-TAVI は 5.7\%）において TAoTAVI, TA-TAVI との成績比較8)では Tsc-TAVI は 30 日死亡 では有意に死亡率が低かった（8.4\% vs. $5.3 \% ， p<0.01)$ の 


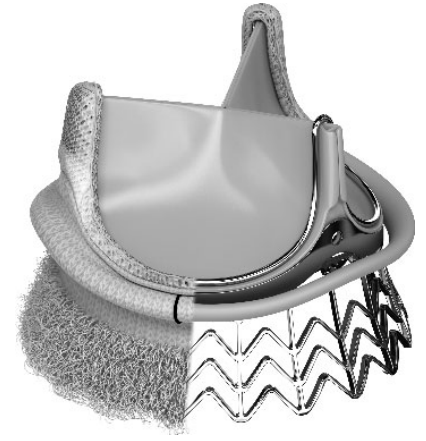

図 1

Intuity Elite（提供元 Edwards Lifescience 株式会社).

に対し，脳梗塞発症に関しては有意に発生率が高かった $(3.1 \%$ vs. $6.3 \%, p<0.05)$.

本邦で Tsc-TAVI を施行する際の重要なポイントの $1 つ$ は脳合併症の回避である. 日本人は鎖骨下動脈の走行が椎 骨動脈分岐末梢で急角度に湾曲している症例が多いので, デバイス挿入に伴う解離には注意を要する。また左椎骨動 脈が弓部から直接起始する症例・右椎骨動脈が, 低形成ま たは狭窄している症例・弓部三分子入口部に血栓を有する 症例や, 動脈硬化性変化が強い症例では特に注意を要する ので，造影 CT や頭頸部 MRI にて鎖骨下動脈打よび弓部 大動脈の性状・走行・ 口径の確認, 椎骨脳底動脈系の形 態・頭蓋内交通の術前精查は必須といえる.

\section{1-2. Rapid deployment valve/Sutureless valve}

Rapid deployment valve/Sutureless valve の使用が期待さ れるシーンは, (1) 心停止時間を短縮したいが, 複合疾患 に対する治療が必要な状況，(2) MICS-AVR などである. 本デバイス留置に付随する問題の 1 つである AV-blockに よるペースメーカー植え込み率は導入初期で $10 \%$ 前後 だったものが，近年では $6.0 \%$ まで, 症例経験数の多い施 設に打いては約 $4.0 \%$ まで改善している.

Rapid deployment valve $の$ Intuity Elite (Edwards Lifescience, 図 1) は, Carpentier-Perimount Magna Ease 生 体弁と TAVI 弁のデザイン・技術の組み合わせで，左室流 出路にステントフレームが圧着されて固定する仕組みに なっている．このため左室流出路狭窄や大動脈弁輪の石灰 化が僧帽弁に向かって連続するような症例では除石灰手技 とサイズ選択に注意を要する。また人工弁の弁座からシー リングクロス部分にかけてはやや Bulky な構造なので, 小さい基部にこれを挿入する際は，3 本の guiding suture の刺出点の確認が案外難しいことがある.

Sutureless valve の Perceval (LivaNova, London, UK) は，ステントフレームは上行大動脈側に位置し sewing ring がないため, 視認性のよい状態のまま弁を留置・展 開しやすい。大動脈基部の血管性状が不良で大動脈切開ラ

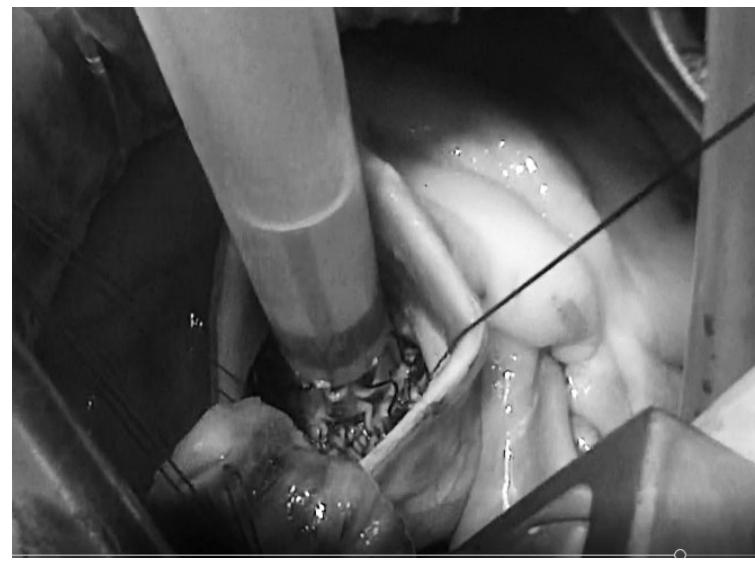

図 2

MICS-AVR での Perceval の留置.

インを高めに設定する場合などでも適応がある。

サイズ展開は， $\mathrm{S} / \mathrm{M} / \mathrm{L} / \mathrm{XL}$ 表記（＝定量的表記がない） ため，あくまで術者がサイジングするときの「感覚」を頼 りに最終的なサイズ決定するので，最適なサイジングには 多少の慣れが必要かもしれない. また Percevalの弁留置 で使用するバルブシステムのシャフトは曲がらないので, 大動脈弁輪に対していかに垂直にシャフトを進められるか (図 2) が AV-block や malposition 防止に重要となる.

\section{MICS に親和性の高いデバイスの普及（自動結紮器・ 左心耳閉鎖デバイス)}

\section{2-1. 自動結紮器 (Cor-Knot)}

心臟大血管領域の中で最も MICS が普及・標準化しは じめているのは僧帽弁領域である. Learning curve が問題 となる ${ }^{9)}$ この手術は, 正中切開での僧帽弁手術に比し心停 止時間を含む手術時間が有意に延長することが課題であっ たため, 連合弁膜症手術や不整脈手術への適応の拡大に関 しては, 従来は施設の成績や経験值が問われるところで あった。

MICS に打いては, knot-pusherへの習熟が重要かつ律 速段階となるが, 自動結紮器 (Cor-Knot, LSI Solutions, NY）が 2021 年 3 月に本邦でも販売開始となった。使用方 法は非常にシンプルでトレーニングにほとんど時間を要さ ないこと，人間の指より遥かにプロファイルが小さくシャ フトが長いため, MICS 特有の狭いワーキングスペース内 でも確実で再現性の高い結紮ができる(図 3)。結紮時の 固定圧も一定となるので均一の固定圧で逢着される ${ }^{10)}$ 点も 魅力である. 問題点はチタンクリップによる結紮の際, 術 者は多少の tactility は感じるが, 通常系結びの際に心臟外 科医がスリップノットテクニックを用いて組織の強度を感 じながら行っている締め込みのような微調整はできないと いうことである。また現時点では保険適用の対象外となっ 


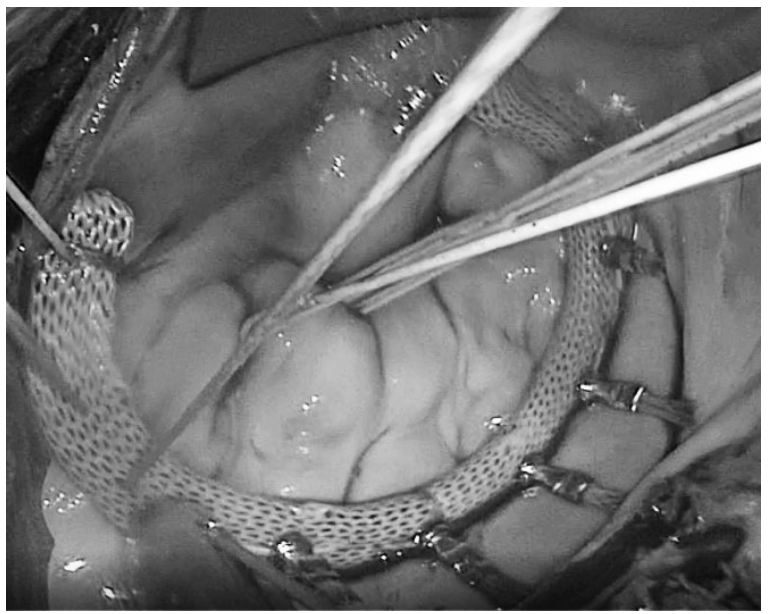

図 3

僧帽弁 MICS における Cor-Knot の使用.

ている点も問題だが，これに関してはデバイスが認知され 普及すれば解消される問題であるので，今後は弁膜症領域 の MICS では使用が広がる可能性も高い。

\section{2-2. 左心耳閉鎖デバイス（AtriClip Pro）}

左心耳閉鎖は従来さまざまな外科的手法が報告されてき た一方で, 遺残血栓や操作部位からの出血りスクが課題 ${ }^{11}$ であった．特に MICSに扎てて，左心耳から出血をき たすと，狭いワークスペースと右の開胸位置からの距離を 考えると recovery shot が非常に困難な状況になりかねな い.

AtriCure 社から販売されている AtriClip Pro1 (AtriCure, Mason, OH）は 2018 年に販売を開始し，2020 年時点で 600 個の実績がある. 左心耳に対して直線的にアプローチ し atraumatic に左心耳根部を clip できる・複合手術にお いて手術時間を短縮できる，などの利点がある ${ }^{12}$. またク リップのラインナップも $35 \mathrm{~mm}$ から $50 \mathrm{~mm}$ まで存在し, Watchman (Boston Scientific, Natick, Massachusetts) で 問題となる左心耳根部が拡張してくびれのない形態に対し ても対応が可能である．本製品も現在保険償還されていな いことが課題である.

\section{MICS 弁膜症手術の今後のストリームは? 一鏡視下手 術/ロボット支援下手術一}

2018 年 4 月の保険改定で胸腔鏡補助下の僧帽弁形成・ 置換術が保険適用となったことで，弁膜症に対する MICS はさらに普及・発展している，昨今話題となっているの が，今後 MICS 弁膜症のメインストリームがいわゆる小 切開の直視下 MICS から高精度モニターを用いた鏡視下 手術（完全内視鏡手術・顕微鏡支援下手術）になるのか, ロボット支援下手術になるのかというテーマである.

鏡視下手術全般に共通することは，モニターの精度・ quality がストレートに手術の comfortability に直結すると いう点である。近年は内視鏡のみならず, ORBEYE (OLYMPUS, JPN) のような手術用顕微鏡システムム ${ }^{13)}$ よって，術野を「瞀き込む」のではなく，システムが $4 \mathrm{~K}$ $3 \mathrm{D}$ モニターに映し出した画像を術者を含めた手術メン バー全員がストレスのない体勢で共有する head up surgery が登場しはじめた.

完全内視鏡の場合, 開胸器が不要で器具の挿入に必要な 孔の大きさを小さくできるので肋間に与えるストレスはき わめて小さく, 疼痛軽減の面でもロボット支援手術と同等 の効果が期待できるが, 孔の大きさがシャフトの長い MICS 用の手術機器の操作性に影響するので, 孔を小さく するとスムーズな操作の習得には一定の修練期間を要す る.

ロボット支援下心臟手術も 2018 年 4 月から僧帽弁形成 術に打いて保険適用となって打り，本邦ではDa Vinci (Intuitive Surgical, USA）が頻用されている。そのメリッ トとしては, ヒトに特有の手ブレがないこと, アームの可 動性が大きく人間の手関節のような制限が少ないこと, 豊 富なアームが併用できること, 創が小さく開胸器を用いな いので術後疼痛はきわめて少ないことなどがある.

一方 Da Vinci で用いる映像モニターの画質は手術遂行 に打いて現状でも問題ないレべルとはいえ，長らくupdate がされていないことから完全内視鏡手術で用いられ るような最新の $3 \mathrm{D}, 4 \mathrm{~K} / 8 \mathrm{~K}$ モニターに比べると comfortability は劣るという声もある. その他に高額な導入・ラン ニングコスト，チーム発足までにかかる時間の長さ (scrub nurse, 麻酔科医, perfusionistには 2 人の外科医の オーダーに協調する訓練が求められる), 手術操作におけ る tactility がないのでデリケートな組織に対する扱いに経 験を要すること，これらを含めた比較的長い learning curve $^{14)}$, 弁膜症における保険適用が僧帽弁形成術に限定 されているので, 万一弁置換へのコンバートを余儀なくさ れたときに保険が適応されないリスクなど課題はさまざま ある。

とはいえ AI 技術の進化とともに，手術支援下ロボット そのものの使用性が向上し先駆者のノウハウ ${ }^{15}$ が普及すれ ば，導入コストは小さくなっていく可能性も今後はありえ る. 事実国内でも Da Vinci 以外の手術支援ロボットの開 発は進んでいる.メディカロイド（兵庫県神戸市）が 2020 年 8 月に製造販売承認を取得した「ヒノトリ」は Da Vinciに類似した設計になっていて，内視鏡外科学会が承 認したトレーニングプログラムも用意されている. 国内外 で販売されている手術支援機器に共通するのは, 豊富な教 育プログラムが存在することである。コロナ禍・ポストコ ロナ時代の遠隔医療という観点でいえば，もし Dual con- 
sole system が確立すれば，自動車運転教習所のように同 じ視野でまず proctor が trainee に hands-on で手術を行わ せつつ手技上のサポートが必要なところだけ proctor が執 刀権を交換して手術を行うということが可能なので, 安全 性を担保しつつ次世代の術者を教育することも可能となる はずである。

総括

今後も心臓外科領域における低侵襲手術のニーズはさら に大きくなっていくことが予想されるが，それぞれの治療 方法・デバイスに特性があり, メリット・デメリットがあ る. 複数ある治療手段を前にして, 患者にとってどれが最 適解になるのか, 患者の耐術能や手術の安全性 ·低侵襲性 はもちろんだが, 術後患者の QOL や患者満足度, 手術の 耐久性など中長期的な観点もふまえて選択・提案すること が肝要である。新しいシステム・手術・デバイスを導入す る際は, 不測の事態も起こりかねないし, 海外の大規模試 験の成績が，人種・体格・対象年齢が異なる日本人にその まま当てはまるとも限らないので, 今後は自施設にとどま らず，さまざまな情報交換・経験のシェアから自分たちの 経験・エビデンスを新たに構築し直すことも重要と考え る。

\section{文献}

1) Yamamoto $\mathrm{M}$, Watanabe $\mathrm{Y}$, Tada $\mathrm{N}$ et al. Transcatheter aortic valve replacement outcomes in Japan: Optimized CathEter vAlvular iNtervention (OCEAN) Japanese multicenter registry. Cardiovasc Revasc Med 2019 ; 20 : 843-51.

2) Kaul S. Raising the evidentiary bar for guideline recommendations for TAVR. JACC 2020 ; 76 : 985-91.

3) Otto CM, Nishimura RA, Bonow RO et al. 2020 ACC/AHA guideline for the management of patients with valvular heart disease: executive summary:a report of the American College of Cardiology/American Heart Association joint committee on clinical practice guidelines. JACC 2021; 77 :
450-500.

4) McDonagh TA, Metra M, Adamo M et al. 2021 ESC Guidelines for the diagnosis and treatment of acute and chronic heart failure. Eur Heart J 2021 ; 42 : 3599-726.

5) Hayashida $K$, Lefèvre $T$, Chevalier $B$ et al. Impact of postprocedural aortic regurgitation on mortality after transcatheter aortic valve implantation. JACC $2012 ; 5$ : 1247-56.

6) Shimura $T$, Yamamoto $M$, Kano $S$ et al. Impact of the clinical frailty scale on outcomes after transcatheter aortic valve replacement. Circulation 2017 ; $135: 2013-24$.

7) Beurtheret S, Karam N, Resseguier $\mathrm{N}$ et al. Femoral versus nonfemoral peripheral access for transcatheter aortic valve replacement. J Am Coll Cardiol 2019 ; 74 : 2728-39.

8) Dahle TG, Kaneko T, McCabe JM. Outcomes following subclavian and axillary artery access for transcatheter aortic valve replacement. Society of the Thoracic Surgeons/ American College of Cardiology TVT registry report. JACC Cardiovasc Interv $2019 ; 12: 662-9$.

9) Holzhey DM, Seeburger J, Misfeld M et al. Learning minimally invasive mitral valve surgery. A cumulative sum sequential probability analysis of 3895 operations from a single high-volume center. Circulation $2013 ; 128$ : 483-91.

10) Lee CY, Sauer JS, Gorea HR et al. Comparison of strength, consistency, and speed of COR-KNOT versus manually handtied knots in an ex vivo minimally invasive model. Innovations $2014 ; 9: 111-6$.

11) Lee R, Vassallo $P$, Kruse $J$ et al. A randomized, prospective pilot comparison of 3 atrial appendage elimination techniques : internal ligation, stapled excision, and surgical excision. J Thorac Cardiovasc Surg 2016; 152 : 1075-80.

12) Shirasaka T, Kunioka S, Narita $M$ et al. Feasibility of the AtriClip Pro left atrium appendage elimination device via the transverse sinus in minimally invasive mitral valve surgery. J Chest Surg 2021; $54: 383-8$.

13) Sun $X$, Okamoto J, Masamune $K$ et al. Robotic technology in operating rooms:a review. Curr Robotics Rep 2021;2: $333-41$.

14) Goodman A, Koprivanac M, Kelava $M$ et al. Robotic mitral valve repair : the learning curve. Innovations 2017 ; 12 : 3907.

15) Balkhy H, Kitahara H. First human totally endoscopic robotic-assisted sutureless aortic valve replacement. Ann Thorac Surg 2020; 109 : e9-11. 